\title{
French Editorials from the Association de Chirurgie Hépato-Bilio-Pancréatique et Transplantation-France (ACHBPT)
}

\author{
Fabrizio Panaro ${ }^{1}$, Karim Boudjema ${ }^{2,3}$, Editorial Office ${ }^{4}$ \\ ${ }^{1}$ Department of Surgery, St-Eloi University Hospital, Montpellier, France; ${ }^{2}$ Association de Chirurgie Hépato-Bilio-Pancréatique et Transplantation- \\ France, Rennes, France; ${ }^{3}$ Service de Chirurgie Hépatobiliaire et Digestive, CHU Rennes, Univ Rennes, Rennes, France; ${ }^{4}$ Hepatobiliary Surgery and \\ Nutrition, AME Publishing Company \\ Correspondence to: Editorial Office. Hepatobiliary Surgery and Nutrition, AME Publishing Company. Email: editor@thehbsn.org.
}

Submitted Jan 15, 2021. Accepted for publication Jan 25, 2021.

doi: $10.21037 / \mathrm{hbsn}-2021-4$

View this article at: http://dx.doi.org/10.21037/hbsn-2021-4

The international journal Hepatobiliary Surgery and Nutrition (HBSN) offers a great opportunity to the French Association of Hepato-Biliary Surgery and Liver Transplantation (ACHBPT). Indeed, each of the monthly "analyzed articles" written by our colleagues will be submitted for publication as an editorial in HBSN. Of course, it has to be written in English and edited by one of our expert members (Video 1, Figures 1,2).

\section{Editors}

* Professor Yilei Mao (Editor in Chief of $H B S N$ );

- Professor Fabrizio Panaro (Topic Editor of HBSN).

\section{Five steps}

(I) Selection of an online first and ahead of print original article dealing with HBP surgery and transplantation.

(II) The very first days of each month, the selected article will be given for analyzing to one of our members (pancreas, bile duct, liver, transplantation, etc.).

(III) The editorial must be back to the editorial office on week 2 for expertise. A French version will be sent for publication on the ACHBPT website. The English version will be sent to $H B S N$.

(IV) The English version will be sent to $H B S N$ via Professor Fabrizio Panaro.

(V) All the editorials must be written according to the $H B S N$ guidelines and revisions could be mandatory.

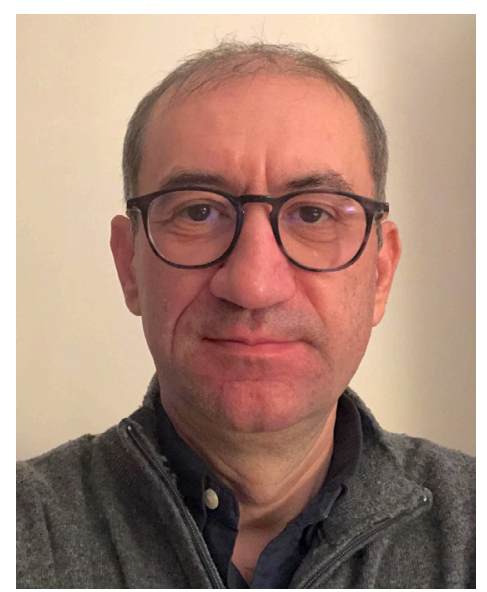

Figure 1 Professor Fabrizio Panaro.

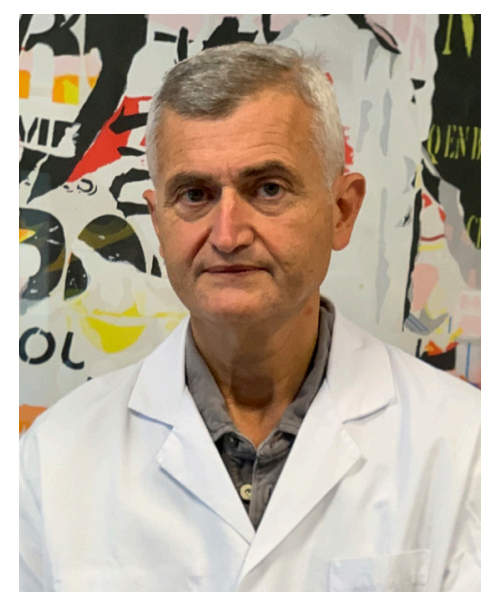

Figure 2 Professor Karim Boudjema. 


\section{Acknowledgments}

Funding: None.

\section{Footnote}

Conflicts of Interest: The authors have completed the ICMJE uniform disclosure form (available at https://hbsn.amegroups. com/article/view/10.21037/hbsn-2021-4/coif). Dr. FP serves as an unpaid editorial board member of $H B S N$. The other authors have no conflicts of interest to declare.

Ethical Statement: The authors are accountable for all aspects of the work in ensuring that questions related to the accuracy or integrity of any part of the work are appropriately investigated and resolved.

Open Access Statement: This is an Open Access article distributed in accordance with the Creative Commons Attribution-NonCommercial-NoDerivs 4.0 International License (CC BY-NC-ND 4.0), which permits the noncommercial replication and distribution of the article with the strict proviso that no changes or edits are made and the original work is properly cited (including links to both the formal publication through the relevant DOI and the license). See: https://creativecommons.org/licenses/by-nc-nd/4.0/.
Cite this article as: Panaro F, Boudjema K, Editorial Office. French Editorials from the Association de Chirurgie HépatoBilio-Pancréatique et Transplantation-France (ACHBPT). HepatoBiliary Surg Nutr 2021;10(1):129-130. doi: 10.21037/ hbsn-2021-4 